\title{
Sixteen-year Prognosis of Treatment-naive Patients with Hepatitis C Infection
}

\author{
Naiv Hepatit C Enfeksiyonlu Hastaların On-altı Yıllık Prognozu
}

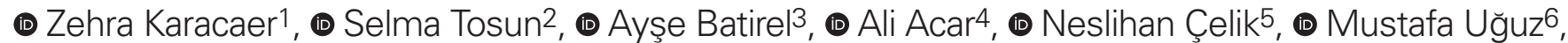 \\ (1) Songül Yavuz², (1) Ercan Yenilmez7, (1) Mustafa Doğan ${ }^{8}$, (1) Tuğba Yanık Yalçın ${ }^{9}$, (1) Büşra Ergut Sezer ${ }^{9}$,

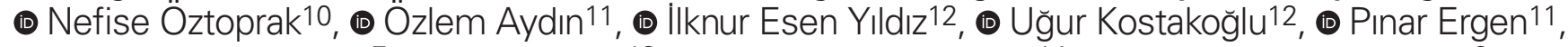 \\ (1) Rıza Aytaç Çetinkaya7, (1) Gül Durmuş13, (1) Ramazan Gözüküçük ${ }^{14}$, (1) Seher Ayten Coşkuner2, \\ (1) Cumhur Artuk1, (1) Emine Fırat Göktaş ${ }^{15}$, (1) Emre Güven ${ }^{16}$, (1) Muhammed Bekçibaşı17
}

\footnotetext{
${ }^{1}$ Gülhane Training and Research Hospital, Department of Infectious Diseases and Clinical Microbiology, Ankara, Turkey 2lzmir Bozyaka Training and Research Hospital, Department of Infectious Diseases and Clinical Microbiology, Izmir, Turkey 3/stanbul Kartal Dr. Lütfi KIrdar Training and Research Hospital, Department of Infectious Diseases and Clinical Microbiology, Istanbul, Turkey ${ }^{4}$ Dışkapı Yıldırım Beyazıt Training and Research Hospital, Department of Infectious Diseases and Clinical Microbiology, Ankara, Turkey ${ }^{5}$ Erzurum Regional Training and Research Hospital, Department of Infectious Diseases and Clinical Microbiology, Erzurum, Turkey 6Silifke State Hospital, Department of Infectious Diseases and Clinical Microbiology, Mersin, Turkey

7Haydarpaşa Sultan Abdülhamid Training and Research Hospital, Department of Infectious Diseases and Clinical Microbiology, Istanbul, Turkey ${ }^{8}$ Çorlu State Hospital, Department of Infectious Diseases and Clinical Microbiology, Tekirdağ, Turkey 9 Sivas Numune Hospital, Department of Infectious Diseases and Clinical Microbiology, Sivas, Turkey 10Univesity of Health Sciences, Antalya Training and Research Hospital, Department of Infectious Diseases and Clinical Microbiology, Antalya, Turkey 11 Istanbul Medeniyet University, Göztepe Training and Research Hospital, Department of Infectious Diseases and Clinical Microbiology, Istanbul, Turkey ${ }_{12}^{12}$ Recep Tayyip Erdoğan University Faculty of Medicine, Department of Infectious Diseases and Clinical Microbiology, Rize, Turkey

${ }^{13}$ Bursa Yüksek Ihtisas Training and Research Hospital, Department of Infectious Diseases and Clinical Microbiology, Bursa, Turkey

14 Hisar Hospital Intercontinental, Department of Infectious Diseases and Clinical Microbiology, Istanbul, Turkey

${ }_{15}$ Ankara Keçiören Training and Research Hospital, Department of Infectious Diseases and Clinical Microbiology, Ankara, Turkey 16Ankara Beytepe Murat Erdi Eker State Hospital, Department of Infectious Diseases and Clinical Microbiology, Ankara, Turkey

${ }^{17 D i y a r b a k ı r ~ B i s m i l ~ S t a t e ~ H o s p i t a l, ~ D e p a r t m e n t ~ o f ~ I n f e c t i o u s ~ D i s e a s e s ~ a n d ~ C l i n i c a l ~ M i c r o b i o l o g y, ~ D i y a r b a k ı r, ~ T u r k e y ~}$
}

Address for Correspondence: Zehra Karacaer MD, Gülhane Training and Research Hospital, Department of Infectious Diseases and Clinical Microbiology, Ankara, Turkey Phone: +90 3123042000 E-mail: zehrakaracaer@yahoo.com ORCID ID: orcid.org/0000-0002-2658-4679 Received: 19.11.2018 Accepted: 16.02.2019

${ }^{\circ}$ Copyright 2019 by Viral Hepatitis Society / Viral Hepatitis Journal published by Galenos Publishing House. 


\section{ABSTRACT}

Objectives: In this study, we aimed to evaluate the clinical course of treatment-naive patients infected with hepatitis $\mathrm{C}$ virus $(\mathrm{HCV})$ who were followed up in various centers in Turkey.

Materials and Methods: This was a retrospective study performed with the participation of 15 centers. Patients aged 18 years and older with HCV infection were included.

Results: A total of 391 treatment-naive patients infected with HCV were included in this study. During the follow-up period, the final values of alanine aminotransferase, aspartate transaminase, and total protein were significantly decreased when compared to the initial values $(p<0.001, p<0.001$, and $p=0.005$, respectively). In the study group, $19.2 \%$ of the patients underwent liver biopsy and $4.1 \%$ underwent transient elastography (FibroScan). An increased histological activity index (HAl) score and fibrosis in the second biopsy were observed in one patient, only increased HAI in two patients and increased fibrosis in one patient, as shown on the FibroScan. In the 16 years of the study period, cirrhosis was radiologically detected in only one patient.

Conclusion: Even if rapid progression is not observed, close monitoring of the clinical findings related to liver failure and fibrosis with invasive or non-invasive methods may be useful.

Keywords: Hepatitis C, naive, prognosis
$0 ̈ z$

Amaç: Bu çalışmada ülkemizin çeşitli merkezlerinde takip edilen naiv hepatit $\mathrm{C}$ virüs $(\mathrm{HCV}$ ) ile enfekte hastaların klinik seyrini değerlendirmeyi amaçladık.

Gereç ve Yöntemler: Bu çalısma retrospektif olarak 15 merkezin katilımıyla gerçekleştirilmiştir. Çalışmaya 18 yaş üstü, HCV enfeksiyonu olan hastalar dahil edilmiştir.

Bulgular: Çalışmada 391 tedavi-naiv HCV enfeksiyonlu hasta yer almıştır. Hastaların takip süresinde son alanine aminotransferase, aspartate transaminase ve total protein değerleri ilk düzeyine göre önemli düzeyde azalmışıı (sırasıyla $p<0,001, p<0,001, p=0,005$ ). Çalışma grubunda hastaların \%19,2'sine karaciğer biyopsisi, \% 4,1'ine elastografi (FibroScan) uygulanmıştır. Takip esnasında bir hastada ikinci biyopside histolojik aktivite indeksi (HAl) ve fibroziste artma, iki hastada sadece HAl'da artma, birinde FibroScan ile fibrozis değerinde artma olduğu gözlenmiştir. Bir hastada 16 yıl içinde radyolojik olarak siroz saptanmıştır.

Sonuç: Hızlı progresyon gözlenmemekle birlikte hastaların izleminde karaciğer yetmezliği ile ilgili klinik bulguların ve invaziv veya noninvaziv yöntemlerle fibrozisin yakın takibi yararlı olabilir.

Anahtar Kelimeler: Hepatit C, naiv, prognoz

Karacaer Z, Tosun S, Batirel A, Acar A, Çelik N, Uğuz M, Yavuz S, Yenilmez E, Doğan M, Yanık Yalçın T, Ergut Sezer B, Öztoprak N, Aydın Ö, Yıldız IE, Kostakoğlu U, Ergen P, Çetinkaya RA, Durmuş G, Gözüküçük R, Coşkuner SA, Artuk C, Göktaş EF, Güven E, Bekçibaşı M. Sixteen-year Prognosis of Treatment-naive Patients with Hepatitis C Infection. 2019;25:19-24.

\section{Introduction}

According to the data from the World Health Organization (WHO), there are 80 million people with chronic hepatitis $\mathrm{C}(\mathrm{CHC})$ infection worldwide. Each year, an estimated 700.000 people die from complications of hepatitis $C$ (1). In the natural course of acute Hepatitis $\mathrm{C}$ virus (HCV) infection, most patients are asymptomatic. Due to the fact that only $10-15 \%$ of patients are symptomatic, few people are diagnosed during the acute phase (2). About 15-45\% of infected persons spontaneously clear the virus within six months of infection without any treatment. The remaining will develop $\mathrm{CHC}$ infection. $\mathrm{CHC}$ is usually recognized during routine scans or after liver disease develops (3).

Although it varies depending on the patient's characteristics and behaviors, such as intensive alcohol use and substance abuse, the risk for developing cirrhosis within 20 years is $15-20 \%$ in $\mathrm{CHC}$ patients, while the risk for developing hepatocellular carcinoma ( $\mathrm{HCC}$ ) in one year is $2-4 \%$ in $\mathrm{CHC}$ patients with cirrhosis (3). Perz et al. (4) reported that $\mathrm{HCV}$ was the causative factor in $27 \%$ patients with cirrhosis and $25 \%$ of patients with HCC, globally. In a study from Turkey, Alacacioglu et al. (5) showed that HCV was involved in the etiology of HCC in $21.3 \%$ of 221 patients.

In this study, we aimed to evaluate the clinical course in HCVinfected patients who were followed in various centers in Turkey.

\section{Materials and Methods}

This was a retrospective study with the participation of 15 centers from Turkey. Patients over 18 years of age, who presented to the infectious diseases and clinical microbiology or gastroenterology outpatient clinics for HCV infections, were included the study.

The patient files were used to obtain the following: patient demographics, biochemical, microbiological, radiological, and histopathological outcomes, the diagnostic method, reasons for not undergoing treatment, and changes in the biochemical, microbiological, radiological, and histopathological findings found during the follow-up.

The principles of the Declaration of Helsinki and Good Clinical Practice Guideline were respected during the entire process of enrolling the patients in the study and collecting/analyzing/ reporting the data. This study was approved by the Local Ethics Committee Izmir Bozyaka Training and Research Hospital, (approval number: 22/11/2016-1). Informed consent was obtained from all participants.

\section{Statistical Analysis}

The study data was transferred to SPSS IBM 22.0 (SPSS Inc., Chicago, IL, United States of America) statistical software and analyzed. The distribution of the data was evaluated using the Kolmogorov-Smirnov test. The descriptive findings of the data as determined by counting were expressed as frequency distribution and percentage, while the measured and non-normally distributed data were expressed as median (minimum-maximum). The initial and final laboratory data of each patient during the follow-up were compared using the Wilcoxon signed-rank test. A p value of less than 0.05 was considered statistically significant. 


\section{Results}

A total of 391 treatment-naive patients with HCV infection were enrolled in this study. The median age of the patients was 53 (19-85) years, with 58.3\% males and $41.7 \%$ females. The median duration of follow-up was 651.5 (8-5827) days; 51.9\% were followed for $\leq 5$ years, $8.4 \%$ for $6-10$ years, $2 \%$ for $11-15$ years, and $37.6 \%$ for $\geq 16$ years.

Distribution of patients with $\mathrm{HCV}$ infection according to time of diagnosis was $0.5 \%$ in $1992-1995,5.4 \%$ in $1996-2000,7.4 \%$ in $2001-2005,14.8 \%$ in $2006-2010$, and $71.9 \%$ in $2010-2016$. In general, the number of patients who maintained regular control examination was low and significantly increased in 2016 (Table 1).

Laboratory findings at the time of diagnosis as median values were as follows: alanine aminotransferase (ALT): 43 (7-872) $\mathrm{U} / \mathrm{L}$, aspartate aminotransferase (AST): 36.5 (7-1.287) $\mathrm{U} / \mathrm{L}$, $\gamma$-glutamyltransferase (GGT): 29 (7-2.558) U/L, total bilirubin: 0.7 (0-11) g/dL, HCV RNA: 285.003 (0-95.000.000) IU/mL, platelets 238.000 (56.000-787.000) cells/ $\mu \mathrm{l}, \alpha$-fetoprotein (AFP): 3.13 (0-300) $\mathrm{ng} / \mathrm{mL}$, total protein: 7.2 (4-9) g/dL, and albumin: 4.1 (3-6) g/dL.

Laboratory findings at the end of follow-up were as follows: ALT: 30 (5-259) U/L, AST 30 (5-199) U/L, GGT: 28 (4-602) U/L, total bilirubin: 0.6 (0.1-10) g/dL, HCV RNA: 50.180 (0-56.000.000) IU/mL,

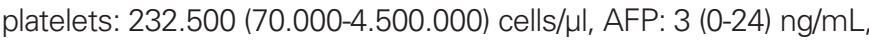
total protein: 7.1 (4-9) g/dL, and albumin: 4 (0-7) g/dL.

During the follow-up, the final ALT, AST, and total protein values were significantly decreased when compared with the initial values $(p<0.001, p<0.001$, and $p=0.005$, respectively). No significant differences were found in the HCV RNA, platelets, GGT, total bilirubin, AFP, and albumin levels ( $p=0.542, p=0.976, p=0.464$, $p=0.248, p=0.933$, and $p=0.220$, respectively). According to the follow-up period, ALT decreased significantly in each period, except $\geq 16$ years, while AST was decreased in $0-5$ years and $11-15$ years, total protein decreased only in the first five years (Table 2).

Seventy-five of the patients in the study group underwent liver biopsy; the median histological activity index (HAl) value was $6(1-6)$ and the median fibrosis value was $1(0-6)$. In the same time period, only 16 patients underwent FibroScan testing, with a median fibrosis value of $1(0-4)$ in these patients.

\begin{tabular}{|l|l|l|}
\hline \multicolumn{3}{|l|}{ Table 1. Distribution of control examinations according to years } \\
\hline Year & Frequency & Percent \\
\hline 2001 & 3 & 0.8 \\
\hline 2002 & 1 & 0.3 \\
\hline 2003 & 3 & 0.8 \\
\hline 2004 & 2 & 0.5 \\
\hline 2006 & 5 & 1.3 \\
\hline 2007 & 1 & 0.3 \\
\hline 2009 & 1 & 0.3 \\
\hline 2010 & 4 & 1 \\
\hline 2011 & 2 & 0.5 \\
\hline 2012 & 7 & 1.8 \\
\hline 2013 & 9 & 2.3 \\
\hline 2014 & 10 & 2.6 \\
\hline 2015 & 37 & 9.5 \\
\hline 2016 & 162 & 41.4 \\
\hline
\end{tabular}

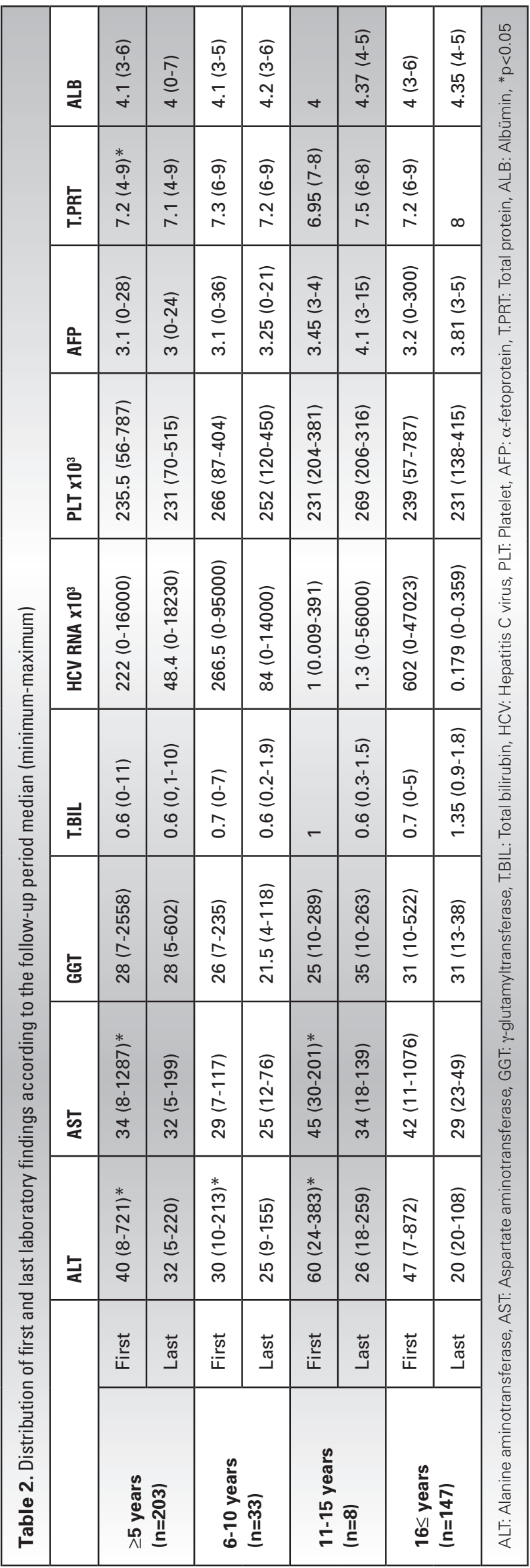




\begin{tabular}{|c|c|c|c|c|c|c|c|c|}
\hline Patients No & HAI & Fibrosis & HAI & Fibrosis & HAI & Fibrosis & $\begin{array}{l}\text { 1. FibroScan } \\
-\end{array}$ & $\begin{array}{l}\text { 2. FibroScan } \\
-\end{array}$ \\
\hline 1 & 5 & 1 & 6 & 2 & 6 & 2 & 4 & 4 \\
\hline 2 & 7 & 1 & 7 & 1 & - & - & 3 & 3 \\
\hline 5 & 3 & 1 & 5 & 1 & - & - & 0 & 0 \\
\hline 6 & 8 & 3 & 8 & 3 & - & - & 2 & 2 \\
\hline 7 & 8 & 2 & 8 & 2 & - & - & 1 & 1 \\
\hline
\end{tabular}

Only seven patients underwent a second and two patients a third biopsy during the follow-up period. The HAl and fibrosis were increased in one patient in whom treatment could not be initiated due to discontinued follow-up, while only the HAl was increased in two patients who did not require or rejected treatment (Table 3). Seven of the patients underwent a second FibroScan during the follow-up period. The fibrosis value evaluated using FibroScan was increased in one patient, but no changes occurred in the remaining six patients. The reasons for not undergoing treatment could not be determined in patients with increased fibrosis scores (Table 3).

At first, two patients were diagnosed with cirrhosis through ultrasonography. In one patient in whom the initial HAl was 14/18 and fibrosis was $4 / 6$, cirrhosis was radiologically stable over the 16 years. The reasons for not undergoing treatment could not be established in patients who developed cirrhosis.

Genotypic analysis was performed in $24.4 \%$ of the patients; $51.1 \%$ were genotype $1 \mathrm{~b}, 34 \%$ were genotype $1,12.8 \%$ were genotype $1 \mathrm{a}$, and $1.1 \%$ were genotype $1 \mathrm{c}$ and genotype $3 \mathrm{a}$.

Overall, the reason for not receiving treatment could only be determined in $56.3 \%$ of patients. The order of frequency of reason that were determined was as follows: interferon (IFN) contraindication or intolerance in $47.3 \%$, refusing treatment in $21.8 \%$, waiting for new treatment options in $14.5 \%$, lost to follow-up in $7.3 \%$, requiring no treatment yet in $3.2 \%$, treatment was planned but not yet initiated in $2.7 \%$, patient healing without treatment in $0.5 \%$, and lost of the patient for any other reason in $0.5 \%$.

\section{Discussion}

In our study, it was observed that the $\mathrm{CHC}$ diagnosis frequency has increased over the last six years. A significant increase was also observed in the number of patients who attended routine control within the last one year. This may be related to the HCV scanning tests included in the mandatory tests for blood donation, operations, or marriage procedures, etc. as well as an increase in the societal awareness of this infection. In addition, the recent introduction of direct-acting antiviral treatments in some countries may be a factor in the increase in the presentation of those patients who desire access to these treatment modalities.

$\mathrm{CHCV}$ infection often follows a progressive course over many years and can ultimately result in cirrhosis, HCC, and need for liver transplantation. Therefore, it is recommended to keep this condition under control; for example, harmful habits in $\mathrm{CHC}$ patients (such as alcohol abuse) should be reduced, hepatitis B vaccination measures should be taken, and the liver fibrosis level should be evaluated. In addition, a proper treatment regimen should be determined while considering several parameters, such as the genotype, comorbidity, pregnancy, and drug-drug interactions, and the efficacy and toxicity of the treatment should be monitored (3). Moreover, human immunodeficiency virus and/or HBV have been found to be associated with a poor prognosis in HCV infection. Obesity and metabolic syndromes increase the incidence of nonalcoholic fatty liver disease, which in turn causes increased fibrosis in $\mathrm{CHC}$ patients. Therefore, increases in insulin resistance and weight should be prevented in the follow-up of these patients with proper diet, exercise, and medical treatments (6).

In this research, it was found that no significant changes occurred in the biochemical and microbiological data during the follow-up, with the exception of the levels of ALT, AST, and total protein in the first five years. However, it has been observed that the change in ALT levels lasted longer. Biochemical and serological tests are good prognostic factors for determining low fibrosis or the absence of fibrosis in the follow-up of HCV patients. However, these tests are insufficient for the diagnosis of advanced fibrosis or cirrhosis (7). An overall evaluation of the severity of liver disease is recommended before treatment, and the identification of cirrhosis or advanced fibrosis is important for both the determination of the treatment options and prognosis after treatment (8). Therefore, the development of fibrosis should be monitored with non-invasive biochemical methods during the patient follow-up, however, when fibrosis is suspected, it may be necessary to go through the more diagnostic methods.

Progression was observed in only one of the seven patients in this study in whom the histopathological controls could be done. The frequency of follow-up with liver biopsy or ultrasonography was low, however, HCV infection did not show rapid courses in the study group, and clinical cirrhosis findings were not observed. Poynard et al. (9) reported a yearly progression rate of 0.133 fibrosis unit in $\mathrm{CHC}$ patients. They found that progression of fibrosis was influenced by male gender, age of initial infection $>40$, and alcohol consumption $>50 \mathrm{~g} /$ day, but the genotype had no effect. The authors also found that cirrhosis developed within an average of 30 years in untreated patients. Moreover, while cirrhosis developed 
within 20 years in $33 \%$ of patients, it did not develop in $31 \%$ of patients, or no progression was seen within at least 50 years.

In one prospective study, it was found that survival in $\mathrm{CHC}$ patients decreased with the presence of cirrhosis, prolonged disease duration, a history of intravenous drug use, and intensive alcohol consumption, but increased with antiviral treatment. Even if there was no cirrhosis at the time of diagnosis, acquiring the disease at an early age significantly increased mortality (8). Although the viral load is an important parameter related to treatment, its effects on the prognosis could not be demonstrated (10). It could be reasonable to evaluate liver fibrosis after the diagnosis in patients with HCV infection detected at an advanced age, as well as those having harmful habits. A liver biopsy is the gold standard, and because it is an expensive and invasive procedure, the WHO recommends the use of non-invasive methods such as aspartate transaminase-to-platelet ratio index (APRI), fibrosis-4 index (FIB-4), or FibroScan in low- and middle-income countries (3). A non-invasive method can also be preferred in cases in which a biopsy cannot be performed.

Based on the results of our study, histopathological and FibroScan examinations were not used frequently. Until recently, liver biopsy was not required in $\mathrm{CHC}$ patients in order to start treatment in Turkey. This may be the reason why radiological and histopathologic evaluations are not performed frequently. Moreover, FibroScan is not available in every center in our country.

Should every patient be treated? Studies using regimens with IFN report that, although the risk of HCC continues in patients with advanced fibrosis who developed a virological response, the liver related morbidity and mortality and the incidence of liver transplantation/death are significantly related $(11,12,13)$. In addition, symptoms and mortality due to severe extrahepatic involvement can also be reduced with HCV treatment. Recent data has shown that antiviral therapies also increase the quality of life in $\mathrm{CHC}$ patients (6). Moreover, the WHO declared "2030 target" to eliminate $\mathrm{HCV}$, but in order to achieve this target, protection measures must be expanded, and at least $80 \%$ of patients must be treated (1).

The current guidelines recommend initiating antiviral therapy in all patients infected with $\mathrm{HCV}$, except for those with short life expectancy for reasons other than liver disease. When this is not possible, there has been a common consensus that it would be appropriate to treat the high-risk population for the complications of the disease or contagion. It is recommended to avoid delays in treatment for patients with advanced fibrosis and cirrhosis $(6,8)$.

Although all HCV-infected patients are treated in high-income countries, if there are no contraindications, the treatment is decided according to the level of fibrosis in low- and middle-income countries (3). In Turkey, until recently, the detection of HCV-RNA positivity was sufficient to start treatment. However, several criteria (such as genotypic analysis and histopathological examination) were implemented in 2016 after the development of direct-acting antiviral therapies.

In the present study, about half of the patients remained untreated because they could not use IFN-containing regimens. A similar situation was demonstrated in a study by Güner et al. (14). However, our patients with observed progression were not included in this group. Since histopathological examination was rarely performed, it was not possible to establish a cause-effect relationship between the introduction of alternative IFN treatments and the progression with the results of this study.

Since a significant number of patients were followed up for 10 years or longer, including the data demonstrating the prognosis of those $\mathrm{CHC}$ patients who were not undergoing treatment makes the present study different from previous similar studies. However, our study has several limitations. First, the lack of generalized rules about the follow-up of the disease caused the centers to exhibit different approaches. Therefore, there was a lack of radiological, biochemical, and/or histopathological data in some of the patients, causing difficulty in comparing the results. In addition, since the histopathological and radiological follow-up rates were low, the cirrhotic patients might not have been sufficiently evaluated. Another limitation was that the presence of HCVrelated complications and their effects on the prognosis were not evaluated. Therefore, further prospective studies are warranted.

\section{Conclusion}

$\mathrm{HCV}$ infection is a disease in which the diagnosis may be delayed because of its silent progression. Even if rapid progression is not observed, close monitoring of the clinical findings related to liver failure and fibrosis with invasive or non-invasive methods may be useful.

\section{Ethics}

Ethics Committee Approval: This study was approved by the Local Ethics Committee (Izmir Bozyaka Training and Research Hospital, approval number: 22/11/2016-1).

Informed Consent: Informed consent was received from all.

Peer-review: Externally peer-reviewed.

\section{Author contributions}

Concept: S.T., Design: S.T., Supervision: S.T., A.A., A.B., N.Ç., M.U., S.Y., E.Y., M.D., T.Y.Y., B.E.S., N.Ö., Ö.A., I.E.Y., U.K., P.E., R.A.Ç., G.D., R.G., S.A.C., C.A., E.FG., E.G., M.B., Data Collection or Processing: A.B., N.Ç., M.U., S.Y., E.Y., M.D., T.Y.Y., B.E.S., N.Ö., Ö.A., I.E.Y., U.K., P.E., R.A.Ç., G.D., R.G., S.A.C., C.A., E.F.G., E.G., M.B., Analysis or Interpretation: Z.K., Literature Search: Z.K., S.T., Writing: Z.K., S.T., A.A., A.B., Critical Reviews: Z.K., S.T., A.A., A.B., N.Ç., M.U., S.Y., E.Y., M.D., T.Y.Y., B.E.S., N.Ö., Ö.A., I.E.Y., U.K., P.E., R.A.Ç., G.D., R.G., S.A.C., C.A., E.F.G., E.G., M.B.

Conflict of Interest: No conflict of interest was declared by the authors.

Financial Disclosure: The authors declared that this study has received no financial support.

\section{References}

1. World Health Organization. Global report on access to hepatitis $C$ treatment, 2016 (cited 2017 Feb 20). Available from: http://www. who.int/hepatitis/publications/hep-c-access-report/en/.

2. Irving WL, Salmon D, Boucher C, Hoepelman IM. Acute hepatitis C virus infection. Euro Surveill. 2008:13.

3. World Health Organization. Guidelines for the screening, care and treatment of persons with hepatitis C infection, 2014 (cited 2017 Feb 20). Available from: http://www.who.int/hiv/pub/hepatitis/ hepatitis-c-guidelines/en/ 
4. Perz JF, Armstrong GL, Farrington LA, Hutin YJ, Bell BP. The contributions of hepatitis $B$ virus and hepatitis $C$ virus infections to cirrhosis and primary liver cancer worldwide. J Hepatol. 2006;45:529-538.

5. Alacacioglu A, Somali I, Simsek I, Astarcioglu I, Ozkan M, Camci C, Alkis N, Karaoglu A, Tarhan O, Unek T, Yilmaz U. Epidemiology and survival of hepatocellular carcinoma in Turkey: Outcome of multicenter study. Jpn J Clin Oncol. 2008;38:683-688.

6. AASLD/IDSA HCV Guidance Panel. Hepatitis C guidance: AASLDIDSA recommendations for testing, managing, and treating adults infected with hepatitis C virus. Hepatology. 2015;62:932-947.

7. Gebo KA, Herlong HF, Torbenson MS, Jenckes MW, Chander G, Ghanem KG; El-Kamari SS, Sulkowski M, Bass EB. Role of liver biopsy in management of chronic hepatitis $\mathrm{C}$ : a systematic review. Hepatology. 2002;36:161-172.

8. European Association for the study of the liver. Electronic address: easloffice@easloffice.eu. EASL Recommendations on treatment of hepatitis C 2016. J Hepatol. 2017;66:153-194.

9. Poynard T, Bedossa P, Opolon P. Natural history of liver fibrosis progression in patients with chronic hepatitis C. The OBSVIRC, METAVIR, CLINIVIR, and DOSVIRC groups. Lancet. 1997;349:825832
10. Seeff LB. Natural history of chronic hepatitis C. Hepatology. 2002;36(5 Suppl 1):35-46

11. Morgan TR, Ghany MG, Kim HY, Snow KK, Shiffman ML, De Santo JL, Lee WM, Di Bisceglie AM, Bonkovsky HL, Dienstag JL, Morishima C, Lindsay KL, Lok AS; HALT-C Trial Group. Outcome of sustained virological responders with histologically advanced chronic hepatitis C. Hepatology. 2010;52:833-844.

12. Van der Meer AJ, Veldt BJ, Feld JJ, Wedemeyer $H$, Dufour JF, Lammert F, Duarte-Rojo A, Heathcote EJ, Manns MP, Kuske L, Zeuzem S, Hofmann WP, de Knegt RJ, Hansen BE, Janssen HL. Association between sustained virological response and all-cause mortality among patients with chronic hepatitis $\mathrm{C}$ and advanced hepatic fibrosis. JAMA. 2012;308:2584-2593.

13. Niederau $C$, Lange $S$, Heintges $T$, Erhardt $A$, Buschkamp $M$, Hürter D, Nawrocki M, Kruska L, Hensel F, Petry W, Hàussinger D. Prognosis of chronic hepatitis C: results of a large, prospective cohort study. Hepatology. 1998;28:1687-1695.

14. Güner R, Tufan ZK, Bulut C, Ersöz G, Batırel A, Kaçmaz B, Kayaaslan B, Baykam N, Ari A, Ogutlu A, Alpat SN, Durdu Y, Gunal O, Gurbuz $Y$, Aydin E, Tosun S, Tabak F. Waiting for interferon-free regimens for chronic hepatitis $C$ patients: A multicenter observational study. Viral Hepatit Derg. 2014;20:95-100. 